\title{
Role of dissemination of microorganisms during laparoscopic appendectomy in abscess formation
}

\author{
Melih Akın, M.D.,' Başak Erginel, M.D., ${ }^{1}$ Abdullah Yıldız, M.D.,, ${ }^{1}$ Banu Bayraktar, M.D., ${ }^{2}$ \\ Fatih Yanar, M.D., ${ }^{3}$ Çetin Ali Karadağ, M.D., ${ }^{1}$ Nihat Sever, M.D., ${ }^{1}$ Ali İhsan Dokucu, M.D. ${ }^{1}$
}

1'Department of Pediatric Surgery, Sisli Etfal Training and Research Hospital, Istanbul;

${ }^{2}$ Department of Microbiology, Sisli Etfal Training and Research Hospital, İstanbul;

${ }^{3}$ Department of General Surgery, Istanbul University Istanbul Faculty of Medicine, Istanbul

\begin{abstract}
BACKGROUND: The aim of this study was to investigate the potential contributory role of laparoscopic appendectomy in the occurrence of postoperative intra-abdominal infections.

METHODS: A prospective single-center study including 48 patients who underwent laparoscopic appendectomy was conducted between August 2010 and September 20II. Two peritoneal samples were obtained from each patient in the pre- and post-appendectomy period. Aerobic and anaerobic microbiological cultures were obtained from the samples. The data were analyzed with statistical methods.

RESULTS: The mean age of the 48 patients (29 male, 19 female) was 10.9 years. Among the pre-appendectomy aerobic cultures, microorganisms were isolated in 18 of the patients (38\%), with Escherichia coli being the most common. In post-appendectomy aerobic cultures, various bacteria were isolated in 7 patients $(14.6 \%)$, with the numbers of bacteria statistically significantly reduced $(p<0.05)$. Anaerobic microorganisms were isolated in 12 patients (25\%) and 4 patients $(8.3 \%)$ in pre- and post-appendectomy cultures, respectively, with Bacteroides fragilis the most common organism; there was a significant reduction in the bacterial count $(p<0.05)$. Each patient was regarded as their own control.
\end{abstract}

CONCLUSION: Our results suggest that laparoscopic appendectomy does not cause an increase in intra-abdominal infections, and particularly not infections associated with anaerobic bacteria.

Key words: Aerobic and anaerobic infections; Bacteroides fragilis; Escherichia coli; intra-abdominal abscess; laparoscopic appendectomy.

\section{INTRODUCTION}

Acute appendectomy is one the most common surgical procedures in children and requires urgent and appropriate treatment; otherwise, it may progress to complicated intraabdominal infections. ${ }^{[1,2]}$ Minimally invasive surgery has gained acceptance for application in acute and complicated appendicitis, as it offers reduced scarring of the abdomen, earlier recovery, and a shorter hospital stay. ${ }^{[3,4]}$ Studies have suggested that

Address for correspondence: Başak Erginel, M.D.

Şişli Etfal Eğitim ve Araştırma Hastanesi, Çocuk Cerrahisi Kliniği, İstanbul, Turkey

Tel: +90 212 - 3735000 E-mail: basakerginel@hotmail.com

Qucik Response Code Ulus Travma Acil Cerr Derg

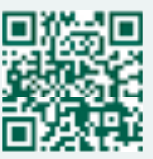

2014:20(I):28-32

doi: $10.5505 /$ tites.2014.40359

Copyright 2014

TJTES an infected appendix can contaminate adjacent tissues during surgery because the intra-abdominal pressure of carbon dioxide $\left(\mathrm{CO}_{2}\right)$ provides a suitable condition for the spread of infection, particularly by anaerobic microorganisms. ${ }^{[5]}$

In this study, we aimed to investigate the effects of laparoscopic appendectomy on the spread of intra-abdominal infections.

\section{MATERIALS AND METHODS}

This prospective study included patients aged 2 to 18 years who underwent laparoscopic appendectomy between August 2010 and September 201I in our Department of Pediatric Surgery. Patients were admitted to the study after parental consent and ethical committee approval were obtained. Demographic variables, clinical presentations, radiological findings, pathological diagnosis, preoperative laboratory parameters (white blood cell count, C-reactive protein [CRP] levels), length of hospital stay, and time since onset of complaints 
were recorded on a standard data sheet. Postoperative abscess formation, wound infections, and antibiotic resistance were recorded. Afebrile patients with normal bowel movement were discharged.

Patients with open appendectomies, Meckel diverticulitis, and appendectomies that had not been completed laparoscopically were excluded. Suspected appendicitis was evaluated pathologically, and patients with negative pathology were excluded.

\section{Surgical Technique}

Laparoscopic appendectomy, utilizing the three-trocar technique, was performed as the standard method. A $10 \mathrm{~mm}$ trocar was inserted into the abdomen via the open technique through an intraumbilical incision. After creating a pneumoperitoneum with $\mathrm{CO}_{2}$ at a pressure between 8 and 10 $\mathrm{mmHg}$, two $5 \mathrm{~mm}$ trocars were introduced at the left lower abdomen and the midline above the symphysis pubis under direct vision of a $5 \mathrm{~mm} 30^{\circ}$ laparoscope. ${ }^{[6]}$ A grasper was used to identify the appendix and to dissect retroperitoneal adhesions. When the tip of the appendix was freed, the mesoappendix was divided by hook cautery. An intracorporeal appendectomy was performed via two-loop ligation, with a division between the loops. The appendix was removed with a grasper held from the closed side, without a bag, through the (umbilical) trocar. After removal of the appendix, a second peritoneal sample was obtained.

\section{Bacteriological Analyses}

Peritoneal samples were obtained twice for isolation of microorganisms. The first peritoneal samples were collected at the beginning of the operation, and the second were obtained following the appendectomy. They were transported to the laboratory in Portagerm bottles recommended for the transport of liquid specimens (BioMerieux, France). All the samples were inoculated on sheep-blood agar, chocolate agar, and MacConkey agar and incubated at $35-37^{\circ} \mathrm{C}$ for $24-48$ hours. Significant growth of microorganisms in culture was identified using conventional and semiautomatic methods, namely BBL Crystal Identification Systems (Becton Dickinson, USA).

\section{Definitions}

Acute appendicitis was defined as inflammation or suppura- tive inflammation of the appendix without perforation and without gangrenous or abscess formation. Complicated appendicitis was defined as gangrenous or perforated appendicitis with or without an abscess or peritonitis. The diagnosis was confirmed with intraoperative macroscopic findings and/ or pathology. ${ }^{[7]}$

\section{Antibiotic Therapy}

All patients received a single dose of amoxicillin clavulanic acid preoperatively in the operating room. If the appendicitis was acute, antibiotic therapy was continued with amoxicillin clavulanic acid. If there were complications, combination therapy with gentamicin and metronidazole was added. The antibiotic therapy was modified according to culture results. ${ }^{[7-9]}$

\section{Statistical Analyses}

The Statistical Package for the Social Sciences (version 16.0 software) was used to analyze the results. The results were expressed as mean \pm standard deviation (SD) for continuous variables and as a percentage for qualitative variables. The distribution of the variables was analyzed with the KruskalWallis test. Differences were assessed using the paired t test or the Mann-Whitney U-test, as appropriate. Nominal variables were assessed by the Pearson chi-square test and by Fisher's exact chi-square test. Wilcoxon's signed-rank test was used for related samples. Statistical significance was considered as $\mathrm{p}<0.05$.

\section{RESULTS}

Forty-eight patients ( 29 male, 19 female) aged 2 - 18 years, with a mean age of 10.9 years, were included in the study. Twenty cases had acute appendicitis, 12 had suppurative appendicitis, 9 had local perforated appendicitis, and 7 had perforated appendicitis and generalized peritonitis. The mean length of the hospital stay was 3.2 (range, I-10) days. The mean CRP level was $54.8 \mathrm{mg} / \mathrm{dl}$ (range, 0.I-284), and the mean leukocyte count was $15.130 / \mathrm{mm}^{3}$ (range, 5.100-29.000). With the use of preoperative ultrasound, the mean noncompressible appendix diameter was found to be $8.3 \mathrm{~mm}$ (range, 6-13). Intraabdominal fluid without the presence of an abscess was found in $15(17.4 \%)$ of the patients, and an abscess was present in I patient (2\%) (Table I).

Table I. Demographic findings of the patients

\begin{tabular}{lcc}
\hline & Mean values & Range \\
\hline Age (years) & 10.9 & $2-18$ \\
Leukocytes $\left(/ \mathrm{mm}^{3}\right)$ & 15000 & $5100-29000$ \\
C-reactive protein $(\mathrm{mg} / \mathrm{dl})$ & 54.8 & $0.1-284$ \\
Diameter of appendicitis on USG $(\mathrm{mm})$ & 8.3 & $6-13$ \\
Length of hospital stay (days) & 3.2 & $1-10$ \\
\hline
\end{tabular}


Aerobic microorganisms were isolated in 18 of the 48 patients (38\%) in the first cultures. Escherichia coli was the most common microorganism, in 12 of the 18 pre-appendectomy aerobic cultures, with an incidence of $66.6 \%$. In 2 patients, both $E$. coli and Pseudomonas aeruginosa were present in the first cultures. Klebsiella oxytoca, beta-hemolytic streptococci, and methicillin-resistant Staphylococcus aureus (MRSA) were also isolated from the pre-appendectomy aerobic cultures. Post-appendectomy aerobic cultures were positive in 7 patients. E. coli was again the most common microorganism in the second cultures, being positive in 5 patients. Both $E$. coli and $P$. aeruginosa were also identified in 2 patients.

E. coli was resistant to ampicillin-sulbactam in 10 patients $(83 \%)$ and to gentamicin in 3 patients (25\%). Ampicillin-sulbactam- and gentamicin-resistant $E$. coli in these 3 patients was sensitive to ceftriaxone (Table 2).

Anaerobic microorganisms were isolated in the pre-appendectomy cultures of 12 (25\%) of the 48 patients. Bacteroides fragilis was the most commonly identified microorganism in $10(83.3 \%)$ of the patients. In 4 of these patients, Peptostreptococcus accompanied Bacteroides, which was the second most common (50\%) anaerobic microorganism. The second culture results were positive in only 4 patients. In the postappendectomy anaerobic cultures, Bacteroides was also the most common microorganism. The decrease in the bacterial count in the post-appendectomy anaerobic cultures was also significant $(p<0.05)$. In 2 patients, Peptostreptococcus accompanied Bacteroides. The number of patients in which a positive culture was reported for each bacterium is listed in Table 3. In our study, each patient acted as their own control in lieu of choosing a control group consisting of open appendectomies.

Postoperatively, exudative fluid developed in 5 patients, and the mean duration to the diagnosis of abscess formation was 5 days (3-7 days). The diagnosis of an abscess was confirmed by ultrasonography. In large, accessible abscesses more than $3 \mathrm{~cm}$ in diameter, percutaneous drainage with ultrasound was performed. E. coli was isolated from abscess cultures in 2 patients, and the remaining 2 only showed leukocytosis. $E$. coli was the most common microorganism in the pre-appendectomy cultures. All the abscesses developed after perforated appendicitis, except one (Table 4). Wound infection developed in 5 of the patients, but it resolved with conservative treatment.

\section{DISCUSSION}

Laparoscopic appendectomy is performed for acute and complicated appendicitis in children. Following the removal of the appendix, infections may occur, except in cases of limited intraluminal acute appendicitis. Complicated appendicitis can

Table 2. Susceptibility/resistance of $E$. coli, the most frequently identified microorganism, to commonly used antibiotics

\begin{tabular}{lcccc}
\hline $\begin{array}{l}\text { E. coli } \\
(\mathbf{n}=12)\end{array}$ & Susceptible & Susceptible (\%) & Resistant & Resistant (\%) \\
\hline Ampicillin-sulbactam & 2 & 16.6 & 10 & 83.3 \\
Gentamicin & 9 & 75 & 3 & 25 \\
Ceftriaxone & 12 & 100 & - & 0 \\
\hline
\end{tabular}

Table 3. Number of patients in which positive culture was reported is listed for each bacterium

\begin{tabular}{|c|c|c|c|c|c|}
\hline \multicolumn{3}{|l|}{ Aerobic bacteria } & \multicolumn{3}{|l|}{ Anaerobic bacteria } \\
\hline & Preapp & Postapp & & Preapp & Postapp \\
\hline E. coli & 10 & 5 & B. fragilis & 4 & 2 \\
\hline \multicolumn{6}{|l|}{ E. colit } \\
\hline$P$. aeruginosa & 2 & 2 & B. fragilis+Peptostreptococcus & 4 & 2 \\
\hline Klebsiella oxytoca & 2 & 0 & Bacteroides spp. & 2 & 0 \\
\hline Beta-hemolytic streptococci & 2 & 0 & Peptostreptococcus & 2 & 0 \\
\hline MRSA & 2 & 0 & & & \\
\hline Total & 18 & 7 & & 12 & 4 \\
\hline
\end{tabular}


Table 4. Ultrasonography (USG) and culture results of patients who developed an abscess

\begin{tabular}{|c|c|c|c|c|}
\hline $\begin{array}{l}\text { Patient } \\
\text { appendicitis }\end{array}$ & $\begin{array}{l}\text { Type of } \\
\text { USG }\end{array}$ & $\begin{array}{l}\text { Preoperative } \\
\text { USG }\end{array}$ & $\begin{array}{l}\text { Postoperative } \\
\text { culture results }\end{array}$ & Preoperative \\
\hline I & $\begin{array}{l}\text { Perforated }+ \text { generalized } \\
\text { peritonitis }\end{array}$ & $\begin{array}{l}\text { Appendix not visualized } \\
\text { Minimal fluid }\end{array}$ & $30 \times 30 \mathrm{~mm}$ abscess & K. oxytoca \\
\hline 2 & Localized perforated & $\begin{array}{l}\text { Appendix } 8 \mathrm{~mm} \text {, } \\
\text { uncompressed } \\
\text { Fluid absent }\end{array}$ & $30 \times 30 \mathrm{~mm}$ abscess & E. coli \\
\hline 3 & $\begin{array}{l}\text { Perforated }+ \text { generalized } \\
\text { peritonitis } \\
\text { Minimal fluid }\end{array}$ & $\begin{array}{l}\text { Appendix } 13 \mathrm{~mm} \text {, } \\
\text { uncompressed }\end{array}$ & $\begin{array}{l}\text { Three abscesses } \\
24 \times 15 \mathrm{~mm}\end{array}$ & $\begin{array}{l}\text { E. coli } \\
\text { Peptostreptococcus }\end{array}$ \\
\hline 4 & Acute & $\begin{array}{l}\text { Appendix } 6 \mathrm{~mm} \text {, } \\
\text { uncompressed, }\end{array}$ & & \\
\hline & & Minimal fluid & $\begin{array}{l}31 \times 62 \times 69 \mathrm{~mm} \\
\text { abscess }\end{array}$ & E. coli \\
\hline 5 & $\begin{array}{l}\text { Localized } \\
\text { Perforated }\end{array}$ & $\begin{array}{l}\text { Appendix not } \\
\text { visualized, } \\
\text { Minimal fluid }\end{array}$ & $\begin{array}{l}\text { Two abscesses } \\
50 \times 18,8 \times 6 \mathrm{~mm}\end{array}$ & E. coli \\
\hline
\end{tabular}

lead to the development of abdominal abscesses and generalized peritonitis. ${ }^{[4,8]}$ During laparoscopic surgery, the anaerobic environment and the manipulation of the appendix may result in infections in the abdomen. In open appendectomies, the abdomen is exposed to normal air containing $20 \%$ oxygen, which is toxic to anaerobic microorganisms. Serour et al. ${ }^{[10]}$ reported that intra-abdominal $\mathrm{CO}_{2}$ in the pneumoperitoneum may increase the risk of intraperitoneal infections in laparoscopic appendectomies. Although some studies have shown no difference between open and laparoscopic appendectomies in terms of infection, we hypothesized that $\mathrm{CO}_{2}$ insufflation may facilitate the spread of bacterial colonization. $\mathrm{CO}_{2}$ insufflations at a continuous pressure $\left(10-12 \mathrm{~cm} \mathrm{H}_{2} \mathrm{O}\right)$, entrance of the ports, movement of the appendix during the preparation of the mesoappendix, and removal of the appendix via intraoperative or transumbilical excision provide a suitable environment for the spread of microorganisms, particularly anaerobes. The intraluminal microorganisms can be flushed out into the intraperitoneal area. Contaminated pieces of fecaliths can also spread throughout the abdomen during aspiration. The contamination can increase complications. ${ }^{[1]}$ Some studies have found that there was no significant bacterial translocation or dissemination of microorganisms in the peritoneum after appendectomy. ${ }^{[2]}$ In our study, we did not observe any increase in the numbers of microorganisms in the post-appendectomy cultures of peritoneal fluid after manipulations associated with appendectomy, aspiration of abscesses, and the removal of the appendix.

Bacteroides is the most common Gram-negative anaerobic bacteria encountered in appendicitis, and it can play a significant role in complications in appendicitis. In pre-appendectomy cul- tures, we isolated these bacteria in $25 \%$ of patients, a number compatible with that reported in the literature. However, $B$. fragilis was present in only four patients in the second batch of cultures, thereby showing a significant decrease.

Low numbers of aerobic bacteria were also found in the second cultures relative to the first (pre-appendectomy) cultures $(p<0.05)$. E. coli has been reported to be the most commonly isolated organism in appendicitis in the literature. ${ }^{[13]}$ Although laparoscopic procedures were associated with decreased numbers of $E$. coli in the second cultures, complications occurred due to antibiotic resistance.

Aided by ultrasonography, abscesses that were larger than $3 \mathrm{~cm}$ and easily accessible were drained percutaneously. Laparoscopic drainage is an effective procedure for intraabdominal abscesses when percutaneous drainage is not possible. ${ }^{[1,13]} \mathrm{E}$. coli was the most commonly identified organism isolated from the pre-appendectomy cultures $(4 / 5,80 \%)$ and from the abscesses $(2 / 5,40 \%)$. The bacterium was also resistant to ampicillin-sulbactam (100\%) and gentamicin (50\%). In the cases that were resistant to ampicillin-sulbactam and gentamicin, the antibiotic therapy was altered to ceftriaxone and tazobactam. The treatment was successful with these drugs. Patients who had abscesses smaller than $3 \mathrm{~cm}$ were treated with antibiotics. We think that the abscesses were the result of ampicillin-sulbactam-resistant $E$. coli. Following the replacement with ceftriaxone and tazobactam, all the abscesses resolved. ${ }^{[8]}$

The numbers of anaerobic organisms were reported to be decreased following laparoscopic appendectomy, but they were 
responsible for complications, such as a longer hospital stay and, particularly, abscess formation. ${ }^{[4, I I]}$ Although the numbers of $E$. coli were decreased in the second cultures following laparoscopic procedures, $E$. coli was responsible for complications due to antibiotic resistance and virulence. $E$. coli was isolated from the abscesses that developed postoperatively.

The limitations of this study are the relatively small number of cases and the difficulty in the production of anaerobic microorganisms in laboratory cultures.

In conclusion, laparoscopy is gaining acceptance in complicated cases of gangrenous or perforated appendicitis in children. $[4,6]$ Suspicions have been raised about a potential increase in the rates of infection, particularly with anaerobic bacteria, due to the anaerobic atmosphere of the pneumoperitoneum, contamination with the contents of the appendix during the preparation of the mesoappendix, and the removal of the appendix via the right paracolic area of the abdomen. ${ }^{[14]}$ Our study showed that laparoscopic appendectomy did not increase intra-abdominal rates of infection, and particularly not with anaerobic bacteria. Intra-abdominal abscesses following laparoscopic appendectomies can develop due to bacterial virulence and the resistance of intraluminal organisms.

\section{Conflict of interest: None declared.}

\section{REFERENCES}

1. David IB, Buck JR, Filler RM. Rational use of antibiotics for perforated appendicitis in childhood. J Pediatr Surg 1982;17:494-500. CrossRef

2. Henry MC, Walker A, Silverman BL, Gollin G, Islam S, Sylvester K, et al. Risk factors for the development of abdominal abscess following operation for perforated appendicitis in children: a multicenter case-control study. Arch Surg 2007;142:236-41. CrossRef
3. Li X, Zhang J, Sang L, Zhang W, Chu Z, Li X, Liu Y. Laparoscopic versus conventional appendectomy--a meta-analysis of randomized controlled trials. BMC Gastroenterol 2010;10:129. CrossRef

4. Mallick MS, Al-Qahtani A, Al-Bassam A. Laparoscopic appendectomy is a favorable alternative for complicated appendicitis in children. Pediatr Surg Int 2007;23:257-9. CrossRef

5. Evasovich MR, Clark TC, Horattas MC, Holda S, Treen L. Does pneumoperitoneum during laparoscopy increase bacterial translocation? Surg Endosc 1996;10:1176-9. CrossRef

6. Suttie SA, Seth S, Driver CP, Mahomed AA. Outcome after intra- and extra-corporeal laparoscopic appendectomy techniques. Surg Endosc 2004;18:1123-5. CrossRef

7. Chan KW, Lee KH, Mou JW, Cheung ST, Sihoe JD, Tam YH. Evidencebased adjustment of antibiotic in pediatric complicated appendicitis in the era of antibiotic resistance. Pediatr Surg Int 2010;26:157-60. CrossRef

8. Liu K, Fogg L. Use of antibiotics alone for treatment of uncomplicated acute appendicitis: a systematic review and meta-analysis. Surgery 2011;150:673-83. CrossRef

9. Vons C, Barry C, Maitre S, Pautrat K, Leconte M, Costaglioli B, et al. Amoxicillin plus clavulanic acid versus appendicectomy for treatment of acute uncomplicated appendicitis: an open-label, non-inferiority, randomised controlled trial. Lancet 2011;377:1573-9. CrossRef

10. Serour F, Witzling M, Gorenstein A. Is laparoscopic appendectomy in children associated with an uncommon postoperative complication? Surg Endosc 2005;19:919-22. CrossRef

11. Nataraja RM, Teague WJ, Galea J, Moore L, Haddad MJ, Tsang T, et al. Comparison of intraabdominal abscess formation after laparoscopic and open appendicectomies in children.J Pediatr Surg 2012;47:317-21. CrossRef

12. Aslan A, Karaveli C, Ogunc D, Elpek O, Karaguzel G, Melikoglu M. Does noncomplicated acute appendicitis cause bacterial translocation? Pediatr Surg Int 2007;23:555-8. CrossRef

13. Clark JJ, Johnson SM. Laparoscopic drainage of intraabdominal abscess after appendectomy: an alternative to laparotomy in cases not amenable to percutaneous drainage. J Pediatr Surg 2011;46:1385-9. CrossRef

14. McKinlay R, Neeleman S, Klein R, Stevens K, Greenfeld J, Ghory M, et al. Intraabdominal abscess following open and laparoscopic appendectomy in the pediatric population. Surg Endosc 2003;17:730-3. CrossRef

\section{KLINIK ÇALIŞMA - ÖZET}

\section{Laparoskopik apendektomi sırasında apse oluşumunda mikroorganizmaların rolü \\ Dr. Melih Akın, ${ }^{1}$ Dr. Başak Erginel, ${ }^{1}$ Dr. Abdullah Yıldız, ${ }^{1}$ Dr. Banu Bayraktar, ${ }^{2}$ \\ Dr. Fatih Yanar, ${ }^{3}$ Dr. Çetin Ali Karadağ, ${ }^{1}$ Dr. Nihat Sever, ${ }^{1}$ Dr. Ali İhsan Dokucu ${ }^{1}$}

${ }^{1}$ Şişli Etfal Eğitim ve Araştırma Hastanesi, Çocuk Cerrahisi Kliniği, İstanbul;

${ }^{2}$ Şişli Etfal Eğitim ve Araştırma Hastanesi, Mikrobiyoloji Kliniği, İstanbul;

3İstanbul Üniversitesi İstanbul Tıp Fakültesi, Genel Cerrahi Anabilim Dalı, İstanbul

AMAÇ: Bu çalışmada, laparoskopik apandektomi operasyonunun karıniçi enfeksiyon oluşumundaki rolü değerlendirildi.

GEREÇ VE YÖNTEM: Ağustos 20। 0-Eylül 20II arasında laparoskopik apandektomi yapılan 48 çocuk hasta çalışmaya alındı. Çalışmamız tek merkezli ve prospektif olarak yapıldı. Her hastadan ameliyat sırasında apandektomi öncesi ve sonrası, aerob ve anaerob olmak üzere dörder adet kültür örneği alındı. Hastaların demografik bilgileri toplandı. Sonuçlar istatistiksel olarak karşılaştırıldı.

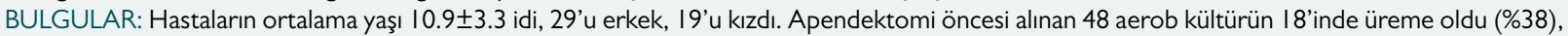
E.coli en sık üreyen mikroorganizma idi. Apendektomi sonrası aerob kültürlerin 7'sinde (\%।5.9) üreme oldu, bakteri sayısı anlamlı olarak azalmıştı $(p<0.05)$. Anaerobik kültürlerde ise 48 hastanın I2'sinde (25\%) apandektomi öncesi, 4'ünde (8.3\%) ise apendektomi sonrası üreme oldu. B. fragilis ensık izole edilen organizma idi. Azalma istatistiksel olarak anlamlı idi $(p<0.05)$.

TARTIŞMA: Bizim sonuçlarımız laparoskopik apendektominin karıniçi enfeksiyon riskini, özelikle de aneorop enfeksiyonların riskini artırmadı̆̆ı yönünde idi.

Anahtar sözcükler: Aerob ve anaerob enfeksiyon; Bacteroides fragilis; Escherichia coli; karıniçi apse; laparoskopik apendektomi.

Ulus Travma Acil Cerr Derg 2014;20(I):28-32 doi: 10.5505/tjtes.2014.40359 